\title{
APSA/JPSA Exchange: A Continuing Tradition
}

\section{Herb Weisberg, Ohio State University and Clyde Wilcox, Georgetown University}

Since 1990, the American Political Science Association has maintained a regular exchange program with the Japan Political Science Association (JPSA). As part of this exchange, Herb Weisberg, Ohio State University, and Clyde Wilcox, Georgetown University attended the 1996 annual meetings of JPSA. The meetings were held October 5-6 in Sapporo, on the northern island of Hokkaido. Our hosts were the international exchange committee of JPSA, chaired by Shin'inchi Kitaoka (Rikkyo University), and including Fumiaki Kubo (Keio University) and Aiji Tanaka (Aoyama Gakuin University). Weisberg and Wilcox were joined by Patrick Dunleavy of the London School of Economics and Political Science, part of an exchange with the British Political Science Association.

A special panel of the JPSA meetings was held in English in which the three visitors gave papers. Shin'inchi Kitaoka chaired the session. Patrick Dunleavy gave a paper on the modern public sector, with Ikuko Toyonaga (Kyushu University) giving comments. Wilcox delivered a paper on the Christian Coalition in American politics, with Tanaka serving as discussant. Weisberg offered a paper on the family gap in voting, with Takashi Yoshino (Waseda University) being the discussant. The panel was very similar to those at APSA meetings. The audience was very involved, with most asking questions after the formal presentations. Indeed, the audience was more active than at most APSA panels.

The APSA-JPSA exchange is reciprocal, with Japanese political scientists attending APSA meetings. Hiroshi Hirano (Meiji Gakuin University) and Ikuo Kabshima (University of Tsukuba) attended and presented papers at the 1996 APSA meetings in San Francisco as part of this exchange.

While in Tokyo, Weisberg and Wilcox gave a talk at the Japan Institute of International Affairs (JIIA) on prospects for the $1996 \mathrm{U}$. S. elections. American politics specialists from universities throughout the Tokyo metropolitan area attended the session. This was another lively session, with most of attendees asking

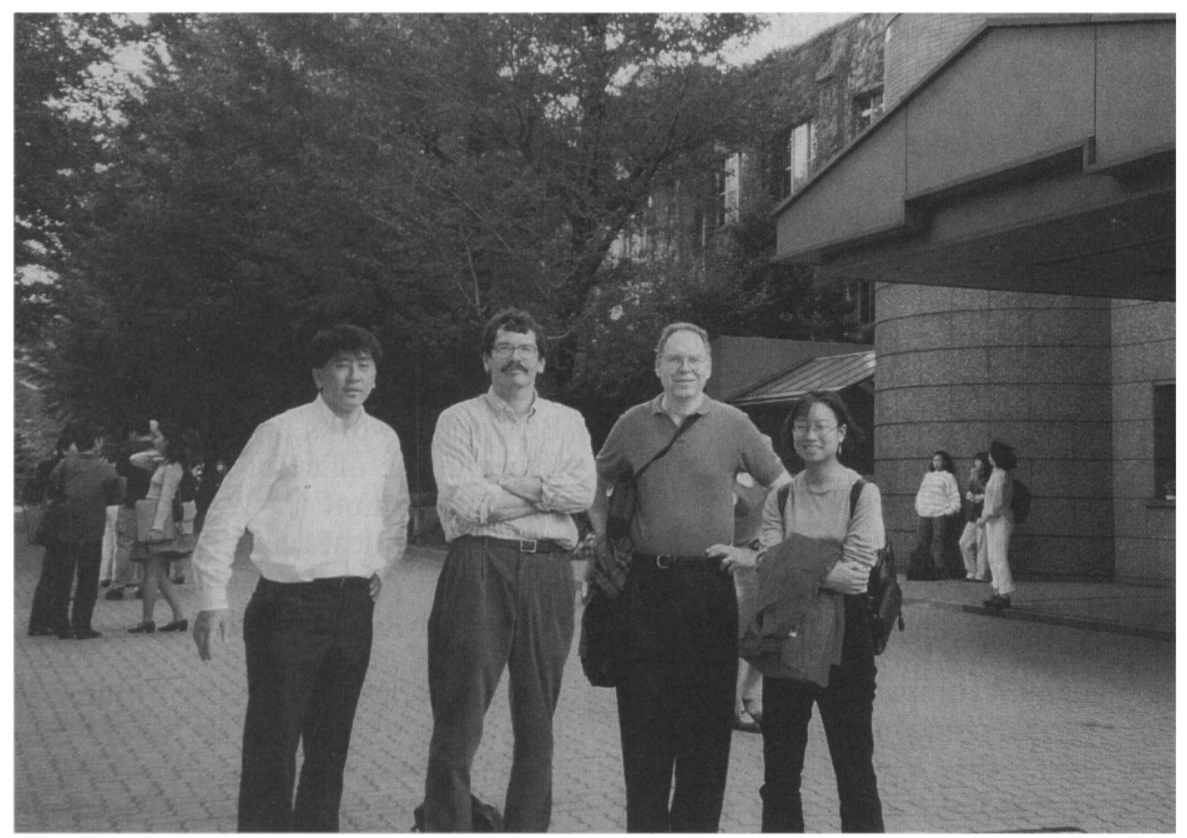

APSA Delegates in Japan. From left: Aiji Tanka, Aoyama Gakuin University, Clyde Wilcox, Georgetown University, Herb Weisberg, Ohio State University, and Maria Toyoda, Georgetown and Aoyoma Gukuin universities. questions about upcoming presidential and congressional elections.

Another interesting part of the visit involved the opportunity to learn more about the Japanese election for their House of Representatives. When the visit was set up, this election was not expected to occur until at least November. However, Prime Minister Hashimoto unexpectedly called the election for October 20. The election was the first under the new electoral system with 300 at-large seats and 200 proportional representation seats. Furthermore, the Japanese system has been realigning in the 1990s along with a substantial increase in political independence. This provided an opportunity for the Japanese and American scholars to exchange information and expectations about their upcoming national elections.

Finally, the JPSA hosts made sure that the U.S. visitors had the opportunity to learn more about Japan. This was Weisberg's first visit to Japan and Wilcox's second visit. The guides in Tokyo were Masahiro Teshima, a graduate student at Aoyama Gakuin University in Tokyo, and Maria Toyoda, a Georgetown University graduate student doing her dissertation work at Aoyama Gakuin University. They showed the visitors parts of Tokyo as well as the Odo-Tokyo Museum which is the city history museum. Maria Toyoda also took the group to Kamakura, a ocean-side town a couple of hours away from Tokyo which is known for its 32 foot high Great Buddha. Their were able to tour Sapporo on Wilcox and Weisberg own, seeing the botanical garden, a museum of the indigenous Ainu people, and two modern art museums. 


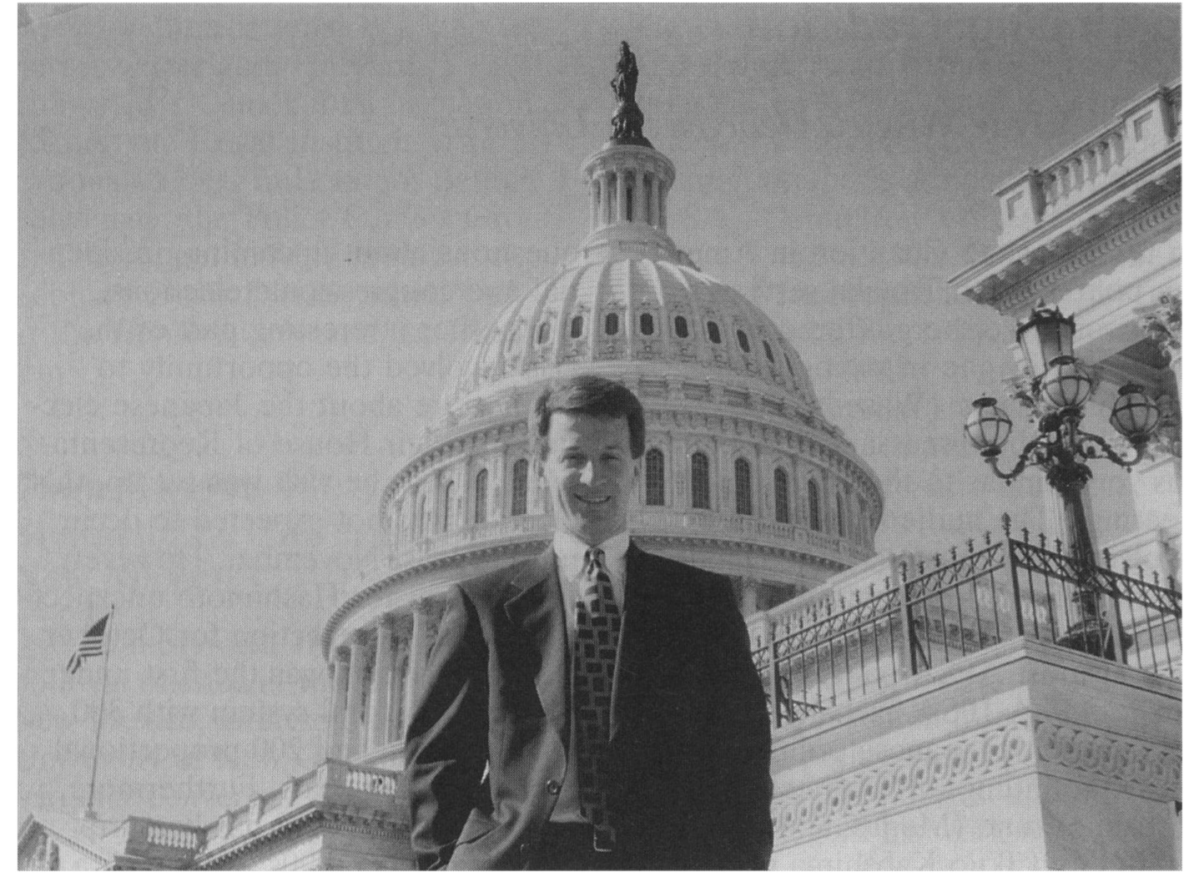

Patrick Sellers

\section{Working for the Minority}

For political scientist Patrick Sellers, whose scholarship has focused on congressional campaigns, changing his professional focus to working in a Senate office came naturally. A self-proclaimed "political hack" and a 1996-97 APSA Congressional Fellow, Sellers has settled into his office in the Capitol building working for Senate Minority Leader Tom Daschle (D-SD). His responsibilities at Indiana University in Bloomington have been temporarily traded in to work on campaign finance reform, judiciary matters, and his main charge of helping the Senate Minority frame its budget message and pitch it to the media, a process he describes as a sometimes "awkward ballet" among his office, the Senate Majority, and the president.

Sellers is a $1994 \mathrm{Ph} . \mathrm{D}$. from Duke University whose major research focus has been on how congressional candidates enhance their credibility among the media and voters by emphasizing issues on which they have built a favorable record of accomplishment. By examining campaign themes of various candidates and comparing them with the backgrounds of the candidates, Sellers has shown why some campaign messages are successful and others fail.
"I applied for a Congressional Fellowship because I wanted to look at the different aspects of American government, and the legislative arena is very different from the electoral arena," Sellers reported But as he began to focus on the legislative side of politics, Sellers was surprised by similarities with the electoral side. "As in campaigning, developing a message is a very important part of the legislative process," Sellers said. "What has impressed me most is how heavily the congressional leadership relies on message development. My background studying message development in campaigns has helped the leadership think about it in the legislative context."

Sellers sees his experience in the Congressional Fellowship Program as an opportunity to expand his research, though, he remains in the "soaking and poking" stage. "I can see my research expanding from work on elections to work on the legislative process. Right now I'm trying to follow the rationale behind the decisions that are made and comparing what happens in strategy meetings to what happens in the media, she said."

This is not Sellers' first stint on Capitol Hill. After graduating from Davidson College in North Carolina, Sellers spent nearly two years working in the office of Representative James McClure Clarke (D-NC) who left the House in 1991. Sellers says his experience in Clarke's office helped frame his work as a political scientist.

"Clarke was in what was the most competitive district in the country during the 1980s. From 1982 until 1990, no candidate won election in that district by more than $1 \%$, so working for Clarke gave me my first good taste of elections, and then I went on to study them."

Though he has enjoyed his time on the Hill, Sellers has no interest in making a run for electoral office. When he returns to Indiana in the fall, Sellers will keep in contact with Capitol Hill by acting as an academic advisor to Indiana undergraduates who serve as interns in Washington.

\section{German Marshall Fund Expands Grant to Congressional Fellows}

The German Marshall Fund of the United States has for 15 years provided funding for German academics to serve as APSA Congressional Fellows. Until now, German Fellows were not consistently funded to participate for the full ten-months of the fellowship program. But in February, the German Marshall Fund agreed to extend the grant for German Fellows to spend the full fellowship year on Capitol Hill, beginning with this year's Fellows.

During the 1996-97 fellowship year, Kirsten Gerstner and Thomas Zittel are the German academics participating as APSA Congressional Fellows. Gerstner recently received her master's degree in political science from the Free University of Berlin and works on human rights issues in the office of Representative Jim McDermott (D-WA). Zittel teaches political science at the University of Mannheim and took his masters degree from Johns Hopkins University in 1990 and his doctoral degree at the University of Mannheim in 1995. He has served his fellowship in the office of Representative Michael Oxley (R-OH) focusing on the issues of environment and technology.

In addition to funding APSA Con- 